\section{Critical Reflection and the Role of the Architectural Educator in the Design Studio}

Jennifer Barker

University of Memphis
For the past nine years I have integrated material from adult education coursework into my teaching. ${ }^{1}$ This has taught me that studying the nature of architecture education through the lens of adult education is a powerful way to engage transformation. As our profession is currently calling for transformative action in architecture education, ${ }^{2}$ critically reflecting on how we have received and how we reproduce the educational experience is extremely relevant.

I highly value critical reflection as a way to successfully challenge oneself to grow and to become more authentic. In considering the teacher's hunch, I thought about why I value critical reflection as an important pursuit. I trace it back to a conversation I had with my mentor early in my teaching career. When asked what she thought architecture students need to be successful, she remarked that students need "a capacity to be curious." Her words deeply resonated with me. In them I found an answer to something I did not realize I was seeking. The "capacity to be curious" sent me on a journey to understand how to develop this capacity in my students.

Assisting our students to develop "uncompromised inquiries to the best of all available knowledge" begins by seeking this ourselves. In essence, teachers of architecture also need a capacity to be curious: about their previous education, about why they teach, about who they are as teachers of architecture. ${ }^{3}$ This paper describes a narrative inquiry into the role of the architectural educator, seeking to understand in what ways architectural educators practice critical reflection within the context of architectural education. This work is part of my greater doctoral research that considers both critical reflection and authenticity in the role of the architecture educator. The site for the research is my own department: I asked my colleagues to share their stories in order that we might collectively come to understand our teaching practice and our departmental ethos, and how we can learn from one another to advance our individual and collective teaching. ${ }^{4}$

\section{REFLECTIONS ON CURIOSITY}

My interest in curiosity framed the way I mined the adult education literature to support my hunch. I found the intersection of creativity, curiosity, and criticality in the works of American educator Parker Palmer and Brazilian educator and literacy advocate Paulo Freire. ${ }^{5}$ Their discussion of what Freire terms "critical consciousness" became a distinguishing path for developing and honing a capacity to be curious. What leads to critical consciousness is a coming to know oneself, where authentic practice is developed through critical reflection. ${ }^{6}$ Exposure to the works of British educator Jennifer Moon and American educator Stephen Brookfield provided the tools by which critical reflection could be utilized to transform oneself and one's community. I also gleaned information from one of the first learning theorists I was introduced to in my adult education coursework: David Kolb and his Experiential Learning model. ${ }^{8}$

Having parsed out a beginning understanding of reflection and critical reflection from the adult education literature, I began looking for its intersection with architectural education. I found the intersection in the work of American educator and organizational theorist Donald Schön. ' Schön offered the tutorial model of the architectural studio as an example of project-based education where knowledge-in-action, 
reflection-in-action, and reflection-on-action were prominent and well demonstrated. Schön's description of the exchange between tutor and student was composed from transcripts produced for the "Architecture Education Study," a ten-year long research project begun in the 1970s at MIT. In a paper based on the case studies of the document, Schön described the importance of both parties being open to the process of the learning environment. In particular, he described the need for novice students to suspend their beliefs and trust that the tutor would move them in the correct direction for their learning; for the tutor, Schön called for the aptitude to see where the learner was having difficulty and to adjust to respond to the learner's need for support and/or clarification. Failure to do so on either side resulted in a learning bind. While Schön recognized that reflection existed in the studio environment, he also recognized that critical reflection on the practice of reflection-in- and on-action was missing. It is in this observation that I found the most obvious and direct application for adult education into architecture education.

Through coursework in educational research I learned there were epistemologies beyond objectivism. ${ }^{10}$ This had a significant impact on my understanding of design as research. I register myself within the constructivist epistemology; by extension of this, I believe the architect to be the instrument by which the architecture is manifested. That is, it is through the architect's translation of client and user needs that the program and site are developed, the design conceived, the drawings prescribed, and the construction answers communicated. It is through the architect's eye; the architect's mind; the architect's heart; the architect's soul. Just as Parker Palmer holds that we teach who we are, so too, do we design who we are. If we wish to advance our practice to become more equitable, in terms of both human and environmental capacity, then we must be willing to critically assess how we came to be the architectural educators we are. Critical consciousness develops across one's lifetime. Freire speaks about this in terms of being unfinished and in a continual state of becoming. Higher education, where the education of the professional architect happens, is an appropriate and meaningful place for the introduction to critical consciousness through critical reflection. ${ }^{11}$ Developing our own prowess and capacity for critical reflection can lead our students to do the same. ${ }^{12}$

\section{CRITICAL REFLECTION}

Schön defines reflection-in-action as "reflective conversation with the materials of the situation." ${ }^{13}$ He holds that "we all have, in greater or lesser degree, the capability of reflecting on what we know as revealed by what we do." ${ }^{14}$ Furthermore, "if we want to teach about our 'doing,' then we need to observe ourselves in the doing, reflect on what we observe, describe it, and reflect on our description." ${ }^{15}$

Brookfield specifies American pragmatism as an intellectual tradition that "sees reflection primarily as the analysis of experience" whereby the "critically reflective practitioner is one who constantly seeks out new information, new understandings of existing practices, and new perspectives" to identify "blind spots. In this tradition the best reflective practitioners are constantly open to revising their assumptions, and are willing to experiment with different ways of supporting those with whom they work." ${ }^{16}$ Brookfield grounds the understanding of "critical" reflection in critical theory: "for reflection to be considered critical it must have as its explicit focus the uncovering, and challenging of power dynamics that frame our decisions and actions." ${ }^{17}$ This includes "hunting" casual, prescriptive, and paradigmatic assumptions-those beliefs that characterize one's conception of the world and how he or she belongs in it ${ }^{18}$-as well as challenging hegemonic assumptions, "those assumptions we embrace as being in our best interests when, in fact, they are working against us." ${ }^{19}$ Hegemonic assumptions are what Webster calls for architectural educators to deeply consider as they rethink the role of the studio (and by extension the juried critique) in architectural education. ${ }^{20} \mathrm{Critical}$ reflection through hunting, uncovering, and challenging assumptions allows for radical shifts in the way educators think and practice.

McLaren finds that "in order to be in a position to engage in critique of teaching, a teacher needs to accept that their personal values can be challenged by others and by the systems in which they teach." ${ }^{21}$ That is, "foundational to critical reflection is the capacity to articulate, communicate and explore fundamental ideas about experiences and beliefs." ${ }^{22}$ McLaren feels that design educators are well poised to develop an understanding of their own teaching, based on the nature of the discipline. She sees overlap in the framework of designing and the conceptual framework for critique that would allow teachers to develop beyond mere reflection to reflexive informed action.

In further qualifying the pragmatist intellectual tradition for critical reflection, Brookfield offers that "pragmatists hold that the way to become more knowledgeable about how to make something work better is through three strategies: (a) constant experimentation; (b) learning from mistakes; and, (c) deliberately seeking out new information and possibilities." ${ }^{23}$ Furthermore, reflective practitioners under this tradition "solve problems by comparing experiences with peers, inviting critique of their efforts, and continually checking and revising their assumptions." ${ }^{24}$ Not only does this align with an attitude of life-long learning, it aligns with critical thinking as it is sought to be developed in design students, through iterative design processes. Addressing the necessity for educators to develop critical reflection begins with learning how current practitioners understand their education and practice and how that informs their teaching and interaction in the design studio.

\section{NARRATIVE INQUIRY - METHODOLOGY AND METHODS}

To gain perspective on the understanding of the architectural educator's view of critical reflection, the methodology must align with the theoretical and epistemological underpinnings. ${ }^{25}$ Because "pragmatism places ordinary, everyday experience as the subject of serious inquiry and the source of serious data," ${ }^{26}$ it makes sense to choose a methodology that does the same. Narrative inquiry, as it is defined by D. Jean Clandinin (and her various co-authors), does just that. For Clandinin, "narrative inquiry begins and ends with a respect for ordinary lived experience." ${ }^{27}$ Like critical reflection, narrative inquiry allows for responsive change on the part of those involved in the process; in fact, it is a goal of the inquiry. The methodology allows for both the researcher and participants to learn from the shared 
experience, and it constitutes the research as temporal, acknowledging that the sharing of stories takes place "in the midst" of carrying out lives. ${ }^{28}$ This has great import for how educators can improve their practice in the tutorial mode of the design studio.

For this narrative inquiry, the following methods were used: life-story interviews focusing on the educator's experience of the design studio (as both a student and a teacher);29 participant journaling over a two-week period of studio design instruction, with focused prompts to address uncovering assumptions; ${ }^{30}$ and, an image-elicited interview utilizing a drawing produced during studio, through the teacher-student interaction. ${ }^{31}$ The latter method recognizes what Schön refers to as the language of design, the responsive talking and drawing that takes place as teacher and student meet for a desk critique. The methods were selected to gather participants' storied experiences of their worlds, acknowledging that "story...is a portal through which a person enters the world and by which his or her experience of the world is interpreted and made personally meaningful." ${ }^{32}$ In addition, the methods encourage the participants to reflect, offering them opportunities for change and affecting a positive experience through the data collection process. ${ }^{33}$ This reflective process also offers opportunities for growth on the part of the researcher.

\section{THE POETICS OF ARCHITECTURAL TEACHING: ANALYSIS, INTERPRETATION, AND REPRESENTATION}

In analyzing and interpreting the interviews and journals, I incorporated "intelligent noticing" or the use of intuition, and incremental chunking, studying larger portions of the texts for ideas. ${ }^{34}$ In particular, I looked and listened for resonances, echoes, and reverberations that expressed "resonant threads or patterns," accounting for the layered and interwoven nature of experiences. ${ }^{35}$ | focused on re-storying the experiences of my participants through poetry, an act of creation I have engaged in since childhood.

The following three poems are interim texts ${ }^{36}$ from the study. The first poem is my reflection on the subject matter prior to collecting participant stories; the second poem is representative of one participant; and, the third poem is representative of shared aspects of all the participants' stories. The second and third poems were constructed via the following method. First, I listened to the interview transcripts and read over the journal entries. While listening and reading, I made notes about resonances or echoes based on the literature review, what I felt as I reflected on my own teaching, as well as commonalities I found across participant stories. I then composed a document containing the most prominent resonances and the raw transcript lines and journal entries that supported these larger ideas. I began sculpting the poems below the raw data, cutting and pasting lines from transcripts and journal entries to form the shape and flow of the poem. As with design, it was an iterative process: I organized the lines of poetry as they came to me. ${ }^{37}$ After I felt that the poems were complete, I connected the lines of the poems back to the larger areas of meaning to make my thinking explicit. This commentary is shown with each of the poems (figures 1-3). The analysis allowed a reflexive turn on the poems, sometimes resulting in small shifts of language and/or structure. When I felt that the poems were polished, I shared them with the participants; they agreed that the poems represented their words and intent well.

The choice of representation through poetry is reflective of the methodology and my authentic practice. Palmer articulates that "for millennia, poetry has helped our species evoke, nurture, and sustain the human heart and connect with each other in supportive communities." ${ }^{38}$ Furthermore, creative representations like poetry "enable us to learn about ourselves, each other, and the world through encountering the unique lens of a person's (or a group's) passionate rendering of reality into a moving, aesthetic expression of meaning." ${ }^{39}$ This responds to the core relational aspect of narrative inquiry as Clandinin defines it: an opportunity to enrich and transform ordinary lived experience for the participants, the researcher, and others. ${ }^{40}$ Ultimately, using poetry "allows us to express something that feels inexpressible in prose." ${ }^{\prime 1}$

\begin{tabular}{|ll|}
\hline the design studio \\
1 memories of past, mix \\
2 with memories of present \\
3 & and I am at once \\
4 & student, instructor, parent \\
5 & it is a strange place to be- \\
6 & caught in between: fear, loneliness, \\
7 & exhilaration, exhaustion, uncertainty. \\
8 & I consider my own need for perfection; \\
9 & my own need to succeed. And I hear \\
10 & in their voices too, the same longing to know: \\
11 & \\
12 & what am I supposed to be learning? will I \\
13 & who am I in this world? how do I fit? why \\
14 & is it this way? does it have to be? \\
15 & And in the end- \\
16 & what are the stories \\
17 & the buildings will tell?
\end{tabular}

Figure 1. Poem: Design Studio.

\section{REFLECTIVE COMMENTARY (FIGURE 1)}

Title: This poem was written two months prior to data collection as a reflective understanding of my view of the design studio-the place where I felt the research was being situated, where the participants were being asked to be present in and tell stories about (for the data collections methods).

Lines 1-4: As I am asking my participants to be reflective, I too, am reflecting on what it was like to be a student in this discipline, what it is like to be a teacher, as well as my other roles, including how these roles might at times conflict (regarding my own expectations, perceptions of expectations from students, colleagues, administrators, etc.).

Line 4: Clandinin discusses the importance of recognizing tensions in the work. I debated including the word parent because I struggle with how much this role has influenced my perception of teaching. It 
has allowed me to be critical of myself, and how I was taught, because it has brought to light conceptions of motherhood, womanhood, parenthood, and principles of care (i.e., I do not have to parent a certain way, simply because I was parented that way and I should not expect that I know how to parent, simply because I was parented). Perhaps a more pertinent realization about this tension it that I have feelings of anxiousness about revealing that I am impacted by this role because of a belief that family should not impact my job (or one's personal life should not interfere with one's vocation) as vocation implies total commitment and a high level of personal sacrifice. Webster discusses the notion of sacrifice in her work, particularly her criticism on design juries. Sacrifice is certainly something I felt from school, and the same feeling was echoed by the participants (though two of them articulated that they were prepared to be fully dedicated, and thus expected levels of sacrifice). Brookfield discusses aspects of sacrifice to vocation when he discusses hunting paradigmatic-hegemonic assumptions.

Lines 6-7: These emotions existed then (as a student) and now (as a teacher). I also found echoes of these emotions in the participants' stories.

Lines 11-14: These are questions that I had long ago that prompted my interest in learning more about the educational process; they still hold meaning for me.

Lines 15-17: If we design in relationship to who we are, then critical reflection is important, as I believe that it would help design students better understand why they design the way they do, and for what purpose, so they do not uncritically accept what they are taught, the designers they study, the designs they admire, and the cities and buildings in which they live and carry out their own storied lives.

\section{REFLECTIVE COMMENTARY (FIGURE 2)}

Lines 1-2: Schön's description centers on the desk critique, the interaction between the faculty member and the student. It seems an important place to start for this participant, as this is their favorite aspect of architectural education.

Line 4: What struck me about this line is that the participant justifies their teaching of other courses because they get to utilize that knowledge in the studio: they would not teach if they could not be involved in studio.

Lines 5-13: Teamwork, to develop all parties involved, is especially important to this participant; they practiced it in their education, in the profession, and in their teaching. They point out that they shifted to a focus to "designing with" after a few semesters of teaching; they stopped making it about their own design and focused on the student. This suggests the more student-centered approach called for by Webster and Mewburn.

Lines 14-15: The participant purposefully does not reproduce certain actions of their educational experience; they are able to articulate why they do not do so, and why others should not.

Lines 18-22: These characteristics reference those mentioned for authenticity and attributes students want according to studies in architecture education. ${ }^{42}$

\section{Listen, Listen with Joy}

1 The desk critique,

2 where I talk with my students directly across a desk about architecture,

3 that's my favorite part of teaching-

4 it's why I do this job: just for the desk critique!

5 Working across the desk with somebody

6 bouncing ideas around

7 (wanting them to do well)

8 it's a cooperative venture;

9 it's designing with,

10 it's co-working,

11 that's where I find the joy.

12 That's what gets me up in the morning:

13 talking to students about their work.

14 I learned long ago,

15 when I was a student,

16 to be a teacher I have to stand up,

17 to be more than just a critic;

18 I need openness and flexibility of mind

19 so that I may be a guide,

20 a challenger,

21 a mentor.

22 But most of all, I should LISTEN. Listen first!

23 In order for design not to be "cheap,"

24 it must be in the service of real authentic living;

25 thus design education requires real authentic experience.

\section{I realize now}

27 (having looked back and asked myself:

28 how do I teach and why do I teach this way)

29 that teaching is a noble thing to do,

30 that it should be part of one's life's work,

31 that it's as important

32 as doing the great buildings.

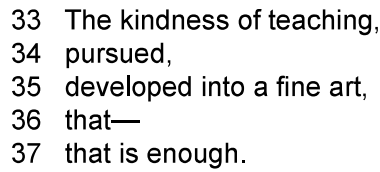

Figure 2. Poem: Listen with Joy. The poem is constructed from the interview transcripts and journal entries of one participant.

Lines 24-25: That the participant advocates for authentic "living" and "experience" in design indicates that they value it; moreover, that they demonstrate an understanding of it in their practice suggests that they are modeling it for their students. ${ }^{43}$

Lines 26-28: Referencing reflectively considering how and why they do what they do, the participant addresses portions of what Webster and McLaren talk about as necessary for critical reflection.

Lines 26-34: The participant has struggled with teaching as a singular practice not in conjunction with professional practice. They have come to terms with teaching as an art that should be practiced to make it exemplary; they credit this to a colleague (at another institution) who is the epitome of this understanding. 


\section{The Expectations We Hold in this Space}

1 There are so many variables, possible solutions-

2 ambiguity-

3 but you learn by doing,

4 by failing,

5 by making decisions based on these,

6 to succeed.

7 I expect you to research, explore numerous alternatives,

8 to integrate knowledge across all your courses-

9 not to come to this space

10 expecting me to make decisions for you,

11 to provide the answer;

12 be serious, totally committed

13 completely prepared

14 with thoughts and questions; with work, but also

15 with a direction for the conversation-

16 discuss things through the use of your

17 exploration: your sketches, your models.

18 Be willing to listen; be open-minded;

19 be excited; be passionate.

20 In this space:

21 I'll ask questions; we'll have a healthy dialogue

22 to get you to critically assess your ideas.

23 This is your opportunity to get the assistance of someone

24 with experience in practice and teaching:

25 I'll provide guidance towards finding solutions,

26 guidance for your own understanding of the problem.

27 We'll work collaboratively; I won't push my design beliefs;

28 rather, we'll have conversations about context, meaning, place;

29 We'll speak of alternatives that might be more fitting,

30 to progress the project.

31 (It is a good learning experience

32 for you to reassess your first thoughts.)

33 In this space:

34 You must understand the importance of testing and failing

35 This is the place to foster explorations,

36 to their farthest extents

37 to support ideations that may fail,

38 to build confidence, judgment skills,

39 to develop your own set of values for making design decisions.

40 Allow for multiple opportunities to safely fail,

41 allow for flexibility in learning how to test, fail, learn, and recover;

42 allow yourself to explore:

43 you must be vulnerable; empathetic; inquisitive.

44 (This is the environment for it!)

45 In this space,

46 it is about self-development:

47 question your assumptions;

48 question your work.

49 It is about Trial and Error:

50 try,

51 err-

52 And, I will, too.

Figure 3. Poem: Expectations. The poem is a collective voice poem, combining lines from the transcripts and journal entries of all participants.

\section{REFLECTIVE COMMENTARY (FIGURE 3)}

Title: It is important to make explicit that these are expectations that faculty hold, to decipher to what degree these are made known to the student, or whether they may remain hidden.

Lines 1-2: Variables, multiplicity of solutions, alternatives, ambiguity: these are all factors that influence student uncertainty, which is discussed in Schön's work. Jeremy Till also talks about this in the form of contingency. ${ }^{44}$

Line 3: Learning by doing and making decisions based on learning in site is part of situated cognition and experiential learning. Information from these, including cognitive apprenticeships, ${ }^{45}$ may prove useful in helping students navigate their education. Both Webster and Mewburn discuss the need for architecture educators to understand situated learning.

Lines 4, 34, 37, 40-41: Failure (and fear of) resonate strongly in the field texts. Schön talks specifically about fear contributing to the learning bind, about students needing a willing suspension of belief to trust the tutor. This suggests further research into elements of successful failures and trust, including resiliency in learning, as well as aspects of experiential education and transformative learning. ${ }^{46}$

Lines 21, 27-28: Dialogue, conversations, and collaboration speak to co-creation and constructivist epistemology (which Webster discusses), as well as narrative methodology. ${ }^{47}$ How do students come to understand this type of creative collaboration? How do they learn to become better at it? Work from Palmer, Brookfield, and Freire can be valuable here. In particular, understanding learning styles, teaching styles, the link between them and their influence on "success" may be meaningful.

Lines 22, 32, 46-48: Criticality is being asked for, thus understanding how it is modeled and taught is important. ${ }^{48}$

Lines 39, 46: A multitude of adult and higher education authors discuss the notion that higher education is about human development, providing support for how it can be accomplished. ${ }^{49}$

Lines 49-51: Trial and error, or heuristic learning, is important to the participants. All participants define the studio in terms of exploration. Becoming conscious of this and finding ways to help students become more comfortable with this method appears relevant.

Line 52: Practicing criticality ourselves is important and appears authentic to the way we want to practice and develop our students. It is imperative to hunt paradigmatic assumptions so that we do not reproduce hegemonic practices. Support for this comes from Brookfield, Freire, and bell hooks, ${ }^{50}$ among others.

\section{IMPLICATIONS FOR EVOLVING TEACHING}

Palmer and Apps contend that authentic teaching comes from awareness of one's self. It is the intention of this paper that to be an affecting and effective teacher, one must understand oneself through critical reflection. Considering some of the key items noticed in the field texts will help my colleagues and myself develop our own critical reflection and advance our practice. Reflecting on these ideas may help other educators as well. Key aspects of this study include:

- $\quad$ Failure is an important part of the process of design education; helping students to be resilient can be very beneficial to 
their learning and personal development.

- Faculty expect a readiness/commitment that they themselves demonstrated, which appeared to help them move past fear/ apprehension. Unpacking and making this explicit may help faculty support student success in this area.

- Faculty defined aspects of educating versus training: to think, create, do research versus to imitate or replicate. They emphasize education over training in their understanding of teaching architecture.

- Teaching at various levels (undergraduate to graduate) has afforded faculty a greater understanding of longitudinal educational expectations and goals. This recognition informs their teaching at multiple levels.

- Faculty recognize that their teaching practice has changed over time; early iterations of their teaching were closer to reproduction of how they were taught; however, they adjusted their teaching over time, predominantly by observing other faculty teach.

- All participants indicated that their role in the studio is to guide, that students should be prepared, and that the role of the design studio is for students to explore. Understanding shared views that inform the collective teaching ethos should be made explicit so that faculty can understand how they inform the curriculum, coursework, policy, procedures, vision, mission, and goals of the department/school/college. Making these explicit also helps faculty consider the "hidden curriculum." 51

- Faculty stories indicated that the language of design can be used to create a shared understanding of learning gain. The production of more drawings during the desk critique indicated enthusiasm on the part of the tutors to be involved in the dialogue, emphasizing buy-in on their part to engage with student ideas. Faculty production was indicative of attentiveness and openness on the part of the student, even if the student appeared to be "stuck" or have little work prepared for the critique. This resonates with the case studies utilized in Schön's work, nearly forty years ago. ${ }^{52}$

Evaluation of the field texts also revealed that architecture educators are addressing some of the issues presented by Schön, Webster, and Mewburn, among others. These include: engaging in reflective practice of studio teaching, the presence of situated cognition as learning through doing, and the use of constructivist language to describe their participation in the studio desk critique.

\section{AFTER EFFECTS}

After my presentation, a fellow presenter in the session asked if I intended to write a poem about my experiences at the conference. The conference was an opportunity for me to consider the field and interim texts among current international and national conversations on architectural teaching; therefore, I embrace the invite to reflect on the experience though poetry and offer it as the conclusion for this paper (figure 4).

\section{The Architecture of Teaching Architecture}

We could, by design, orchestrate this thing we call teaching; Map it out, like a time line, to give us points, nodes, edges by which to become critically conscious of the things that brought us here:

confidence in what we are doing, wondering

what we could do better, longing

to engage meaningfully in the discourse of

the world we live in now.

(The one our students are living in, too.)

What joy there is

in coming together to speak of these things-

our doubts, our successes, our musings,

our lives lived and now intertwining-

re-framing our learning to become better teachers

by engaging in global discussions.

I walk away inspired!

I know others walk away feeling left

with emptiness in the cup of

knowledge and practice they hoped to fill.

I am not discouraged.

I hear in the low murmur of voices, whisperings of tremors, movements that seek to shake the foundations, igniting embers in Stanford's September.

The winds are shifting; the breeze that blows is warm.

It comforts me to be swept into the path of

a blazing passion; to seek who we are now and

who we will become.

It is not nearly so far off as I once imagined.

Figure 4. Poem: Teaching Architecture.

\section{Notes}

1 My teaching journey began a couple years before I formally began teaching. While working as an architectural intern I helped the firm's partners learn AutoCAD. In doing this I learned two key things. First, when I was working with one of the partners, he asked that I tell him exactly what I was doing while I was doing it. Some years later I would come to understand that he was asking me to externalize my knowing, to make it explicit for his learning. Second, I realized that I had a passion for teaching; it gave me great pleasure to know that I had helped someone else achieve a goal with the information that I knew. Realizing that I wanted to teach influenced my decision to pursue post-graduate studies. When I returned to school, I did so with the specific intent to teach. Thus, I simultaneously pursued advanced architecture education as well as coursework in higher and adult education.

2 "Guides for Equitable Practice," American Institute of Architects, 2019, https://www.aia.org/resources/6076046-guides-forequitable-practice. "Call to Action," Association of Collegiate Schools of Architecture, 2019, http://www.acsa-arch.org/programs-events/ conferences/fall-conference/2019-fall-conference/call-to-action.

3 Such critical evaluation has been proposed by several authors: Helena Webster, "Facilitating Critically Reflective Learning: Excavating the Role of the Design Tutor in Architectural Education," Art, Design \& Communication in Higher Education 2, no. 3 (2004). Helena Webster, "The Architectural Review: A Study of Ritual, 
Acculturation and Reproduction in Architectural Education" Arts and Humanities in Higher Education 4, no. 3 (2005). Helena Webster, "The Analytics of Power: Re-presenting the Design Jury," Journal of Architectural Education 60, no. 3 (2007). Helena Webster, "Architectural Education after Schön: Cracks, Blurs, Boundaries and Beyond," Journal for Education in the Built Environment 3, no. 2 (2008). Inger Mewburn, "Lost in Translation: Reconsidering Reflective Practice and Design Studio Pedagogy," Arts and Humanities in Higher Education 11, no. 4 (2012). Susan McLaren, "Critiquing Teaching: Developing Critique through Critical Reflection and Reflexive Practice," in Critique in Design and Technology Education, eds. P. Williams and K. Stables (Springer Singapore, 2017), https://doi.org/10.1007/978-981-10-3106-9_10. Leonard J. Waks, "Reflective Practice in the Design Studio and Teacher Education," Journal of Curriculum Studies 31, no. 3 (1999). Leonard J. Waks, (2001). "Donald Schön's Philosophy of Design and Design Education," International Journal of Technology and Design Education 11, no. 1 (2001).

4 I am thankful to have a supportive and accommodating faculty who share in my interest to improve their teaching.

5 Parker Palmer, The Courage to Teach: Exploring the Inner Landscape of a Teacher's Life (San Francisco: Jossey-Bass, 1998). Paulo Freire, Pedagogy of the Oppressed (New York: Continuum, 1970/2000). Paulo Freire, Pedagogy of Freedom: Ethics, Democracy, and Civic Courage (Boulder, CO: Rowman \& Littlefield Publishers, 1998/2001).

6 Patricia Cranton and Ellen Carusetta, "Perspectives on Authenticity in Teaching," Adult Education Quarterly 55, no. 1 (2004). Carolin Kreber et al., "What do You Mean by 'Authentic'? A Comparative Review of the Literature on Conceptions of Authenticity in Teaching," Adult Education Quarterly 58, no. 1 (2007). Jack Mezirow and Associates, Fostering Critical Reflection in Adulthood: A Guide to Transformative and Emancipatory Learning (San Francisco: JosseyBass, 1990). Stephen D. Brookfield, Becoming a Critically Reflective Teacher (San Francisco: Jossey-Bass, 1995). Palmer, Courage to Teach. Freire, Pedagogy of Freedom.

7 Jennifer A. Moon, Reflection in Learning and Professional Development: Theory and Practice (Hoboken: Taylor and Francis, 1999/2006). Stephen D. Brookfield, The Skillful Teacher: On Technique, Trust, and Responsiveness in the Classroom, 2nd ed. (San Francisco: Jossey-Bass Publishers, 2006).

8 Kolb's descriptions of how learners prehend and transform information was noteworthy to me, not only because it provided information that was immediately accessible and practical to my teaching, but because it helped me realize that reflective observation was what I had been using for a very long time to make meaning of my learning. David Kolb, "Learning Styles and Disciplinary Differences," The Modern American College, 1 (1981). David Kolb, Experiential Learning as the Science of Learning and Development (Englewood Cliffs, NJ: Prentice Hall, 1984).

9 Donald Schön, "Learning a Language, Learning to Design," in Architecture Education Study (Mellon Foundation, 1981). Donald Schön, The Reflective Practitioner (San Francisco: Jossey-Bass, 1983). Donald Schön, "The Architectural Studio as an Exemplar of Education for Reflection-in-action," Journal of Architectural Education 38, no. 1 (1984). Donald Schön, The Design Studio: An Exploration of its Traditions and Potentials (London: RIBA Publications, 1985). Donald Schön, Educating the Reflective Practitioner (San Francisco: Jossey-Bass, 1987). Donald Schön, "Knowing-in-action: The New Scholarship Requires a New Epistemology," Change: The Magazine of Higher Learning 27, no. 6 (1995)

10 Michael Crotty, The Foundations of Social Research: Meaning and Perspective in the Research Process (London: Sage, 1998/2015).

11 Arthur W. Chickering, The Modern American College (San Francisco: Jossey-Bass, 1981). Stephen Brookfield, Teaching for Critical Thinking: Tools and Techniques to Help Students Question Their Assumptions (San Francisco: Jossey-Bass, 2012).

Brookfield, The Skillful Teacher. Palmer, Courage to Teach. McLaren, "Critiquing Teaching."

12 In his paper in the Architecture Education Study, Schön mentions this very thing: "it is possible to discuss, and encourage reflection on, the teaching/learning situation itself-on the assumptions of the willing suspension of disbelief, on the cognitive work and the reciprocal inquiry that are essential to its success, and on the ways in which students' and teachers' theories-in-use facilitate or inhibit this work. This reflection can be made integral to the performance of the concrete tasks of the studio. By showing how reflective capacity in their own inquiry can be used in the search for congruence of meanings, teachers of design can create conditions in which students are more likely to become attentive to, and think about the processes by which they restructure their own meanings. Learning the language game called 'designing' can then become an experience of inviting and nurturing one's own reflective capacity" "Learning a Language," 468. See also Ann Quinlan, Linda Corkery, and Nancy Marshall, "Positioning the Design Tutor's Presence in the Design Studio for Successful Student Design Learning," in Connected 2007: International Conference on Design Education (2007).

13

14

15

16 Reflection?" in Researching Critical Reflection: Multidisciplinary Perspectives, eds. Jan Fook et al. (London: Routledge, 2016), 13.

17

\section{Francisco: Jossey-Bass, 1995).}

19 Brookfield, "What Exactly is Critical," 13.

20 Webster, "Facilitating Critically Reflective Learning," "The Architectural Review ," "The Analytics of Power," "Architectural Education after Schön."

21 "Critiquing Teaching," 174.

22 Gillian Ruch, "Relational Practices in Critical Reflection: The Role of Communication and Containment," in Researching Critical Reflection: Multidisciplinary Perspectives, eds. Jan Fook et al. (London: Routledge, 2016), 27.

"What Exactly is Critical," 14

24 Ibid., 15.

25 Crotty, Foundations of Social Research.

26 Brookfield, "What Exactly is Critical," 15.

27 D. Jean Clandinin, Engaging in Narrative Inquiry (London: Routledge, 2016), 18.

28 Ibid.

29 The life-story interview gathered stories surrounding the participant's understanding about how he or she came to architecture as a course of study (and by extension, career), as well as motivation for teaching. Participants were asked to describe their architectural ethos, as well as the ethos of their architectural environment as a student, and the ethos of their current teaching environment.

30 The participants were asked to keep a two-week personal journal of their teaching in a design studio, during a semester of teaching. The participants were provided a guide to develop their journal entries based on the works of Moon, Brookfield, and Palmer. Moon's reflective process was used to develop the daily questions of the reflective journaling exercise. Brookfield's work regarding hunting assumptions was accessed in the reflective journaling process, both in the daily writing prompts as well as pre- and post-class notes. As reflective journals encourage learners to reflect on their previous experiences, this method seems appropriate for mitigating the gap that Schön addresses in his critique of the reflection-in-action 
process of the faculty-student interaction within the studio review. That is, under the right guidance, and through thoughtful execution of the exercise, the participant may become aware (or more aware) of the presence of reflection during these routine activities by acknowledging that reflection is taking place. This may help the participant to develop his/her understanding of, and capacity for, reflection. The positioning of the image-elicited interview, which occurred sometime after the reflective journaling exercise, allowed for follow-up to the ideas first explored in the journaling exercise.

31 In the image-elicited interview, participants were asked to provide an example of drawings produced during a design studio session. The participants were prompted to talk about the image, setting the scene for the desk critique, and how s/he and the student responded within the setting. Additionally, participants were asked to describe their typical faculty-student interaction for a desk critique; how they learned to perform/carry out desk critiques; and, their thoughts on the apprenticeship model of architecture education.

32 Michael Connelly and D. Jean Clandinin, "Narrative Inquiry," in Handbook of Complementary Methods in Educational Research, eds. Judith Green, Gregory Camilli, and Patricia Elmore (Washington, D.C.: American Educational Research Association, 2006), 477.

33 Steinar Kvale and Svend Brinkman, Interviews: Learning the Craft of Research Interviewing (Los Angeles: Sage Publications, 2009).

34 Gary Thomas, How to do your Case Study: A guide for Students and Researchers (Thousand Oaks, CA: Sage, 2011).

35 Clandinin, Engaging in Narrative Inquiry, 132.

36 Interim texts are what Clandinin refers to as data analysis that is moving from its collected form towards its final presentation, which is still in process and negotiable.

37 In some instances, this meant that I wrote while I listened to the transcripts or as soon as I reread the lines of transcript pasted into the new document. At other times, I felt that I needed to reread the raw data within the new document in order to strategize the organization of the poem and make sure the content was covered sufficiently.

38 Parker Palmer, "Foreword" in Teaching with Heart: Poetry that Speaks to the Courage to Teach, eds. Sam M. Intrator and Megan Scribner (San Francisco, Jossey-Bass, 2014), xxv.

39 Laura L. Ellingson, "Analysis and Representation Across the Continuum," in The SAGE Handbook of Qualitative Research, 4th ed., eds. Norman K. Denzin and Yvonna S. Lincoln (Los Angeles: SAGE, 2011), 599.

40 Engaging in Narrative Inquiry.

41 M. Prendergast and G. Belliveau, "Poetics and Performance," in Reviewing Qualitative Research in the Social Sciences, eds. Audrey A. Trainor and Elizabeth Graue (New York: Routledge, 2013), 202.

42 In their action research on faculty-student interaction within the studio environment, Quinlan, Corkery, and Marshall found that "students place highest value on the personal qualities of the design tutor believing these are most important to their successful learning" ("Positioning the Design Tutor's Presence," 1). From this, the authors conclude "that the quality of 'presence' in a design tutor can be enhanced by adopting a reflexive approach that positions learning at the forefront of a community of practice in design education" (1). Furthermore, the authors note that "unequivocally, students in all programs and across all years believe the ideal design teachers should have, above other characteristics, certain personal qualities such as: being patient, compassionate, understanding, approachable, consistent, fair and enjoy teaching design studio" (2). Similar to Quinlan, Corkery, and Marshall, Webster found in her research that architecture students qualified the ideal tutor as one who showed enthusiasm, openness, two-way communication, mutuality, empathy and counseling, and co-management ("Facilitating Critically Reflective Learning"). Webster relates this to the description of teacher as liminal servant, a description she utilizes from Peter McLaren's work, Schooling as a Ritualised Performance. Webster offers that a teacher displaying these characteristics "is interested in assisting the learner to construct their own knowledge (deep learning) through addressing both the cognitive (scaffolding) and social (the underlying belief systems [sic] values, norms, behaviours [sic] implicit in the disciplinary area) dimensions of learning." This type of teacher "adopts a student-centered approach to the role of tutor by assisting the student to manage and construct his or her own learning through critically reflective dialogue" ("Facilitating Critically Reflective Learning," 109). Student reflections from her research indicated to Webster that there were very few examples of this type of educator in the study context.

43 Palmer and Brookfield find that an integral part of recognizing the student dimension within the learning environment (holistic teaching) is allowing the student to see the whole individual of the teacher. This is part of showcasing authenticity, an individual's "personalities, preferences, values, and ways of being in the world" (Cranton and Carusetta, "Perspectives on Authenticity," 5). By allowing their authentic self to appear through their teaching, educators invite students to participate in the learning environment in a similar way (Palmer, The Courage to Teach). This invitation allows the student to place his or her whole being into the participation of sharing and meaning-making, thereby offering a chance for transformation (Freire, Pedagogy of the Oppressed, Pedagogy of Freedom). To Webster's point, it allows for recognition of a whole person, an identity made up of more than just mental functioning ("Facilitating Critically Reflective Learning"). In adult education, the concept of whole person learning is defined as necessary for life-long learning, and it exists for both the student and the teacher, as this belief recognizes that both parties are co-learners. See also Jerold W. Apps, Teaching from the Heart (Malabar, FL: Krieger, 1996).

44 Jeremy Till, Architecture Depends (Cambridge, MA MIT Press, 2009).

45 See Sharan B. Merriam and Laura L. Bierema, Adult Learning: Linking Theory and Practice (San Francisco: Jossey-Bass, 2014). Sharan B. Merriam, Rosemary S. Caffarella and Lisa Baumgartner, Learning in Adulthood, 3rd ed. (San Francisco: Jossey-Bass, 2007). "Modeled after craft apprenticeships, in a cognitive apprenticeship, novices are taught to think about what they are doing as well as learning the skills associated with the activity" (Merriam and Bierema, Adult Learning, 119). This still involves a master modeling behaviors and thinking to a novice (Merriam and Bierema, Adult Learning), but it also includes scaffolding or phasing that fosters self-directed learning and generalizing that supports reflective practice (Merriam, Caffarella, and Baumgartner, Learning in Adulthood). For this approach to be effective, the doing and thinking of the master must be made explicit, as well as the thinking visible from teacher to student, and student to teacher (). This can be fostered through critical reflection on practice (Merriam, Caffarella, and Baumgartner, Learning in Adulthood; Merriam and Bierema, Adult Learning), thus further emphasizing the need for educators to practice critical reflection.

46 For successful failures see Eve S. Weinbaum, To Move a Mountain: Fighting the Global Economy in Appalachia (New York: New Press, 2004). For trust and resiliency in learning see Jane Kathryn Vella, Learning to Listen, Learning to Teach: The Power of Dialogue in Educating Adults (San Francisco: Jossey-Bass, 2002). For experiential education and transformative learning see the works of John Dewey, David Kolb, and Jack Mezirow.

47 This is an important notation because both Webster ("Facilitating Critically Reflective Learning," "Architectural Education after Schön") and Mewburn ("Lost in Translation") advocate for a constructivist approach to architectural education to foster student-centered learning. Brookfield's emphasis on intersecting critical reflection with critical theory also advocates a constructionist point of view for education, as critical theory is often situated in social constructivist epistemology (Crotty, The Foundations of Social Research).

48 Webster argues that "tutors need to be more critically reflexive about their tutorial practices" ("Facilitating Critically Reflective Learning," 110-111) through developing "a student-centered approach to the 
role of tutor by assisting the student to manage and construct his or her own learning through critically reflective dialogue" (109).

49 Among these are Arthur Chickering, William Perry, Robert Keegan, Paulo Freire, Parker Palmer, and Stephen Brookfield.

50 bell hooks, Teaching to Transgress: Education as the Practice of Freedom (New York: Routledge, 1994). bell hooks, Teaching Community: A Pedagogy of Hope (New York: Routledge, 2003). bel hooks, Teaching Critical Thinking: A Practical Wisdom, (New York: Routledge, 2010).

51 Webster, "Facilitating Critically Reflective Learning."

52 Schön, "Learning a Language." 